\title{
Pembuatan Filter Air Sungai dan Penyediaan Penampungan Air Bersih di Desa Penadaran
}

\author{
Adelia Puspitasari $^{1}$, Agnes Oktavi Maharani ${ }^{2}$, Ratih Pramitasari ${ }^{3}$, Syahiful Yudhi Nugroho ${ }^{4}$, Wahyuni \\ Ainuly Umayah ${ }^{5}$, Kania Salma Nur Prastiwi ${ }^{6}$, Berlian Totti Viala ${ }^{7}$, Agil Fahrudi Hibatulla ${ }^{8}$, Rani \\ Hardiningtyas $^{9}$, Deyani ${ }^{10}$, Alif Maulana Iqbal ${ }^{11}$, Supriyadi ${ }^{12}$ \\ ${ }^{1-10}$ Kesehatan Masyarakat Universitas Dian Nuswantoro \\ ${ }^{11}$ Kesehatan Lingkungan Universitas Dian Nuswantoro \\ ${ }^{12}$ PT Tirta Gajah Mungkur \\ Email: ${ }^{3}$ ratih.pramitasari@dsn.dinus.ac.id
}

\begin{abstract}
Penadaran Village is a village in Gubug District, Grobogan Regency, Central Java Province. The dry season makes residents in Penadaran Village experience problems with clean water sources. The purpose of community service is to make filters and provide clean water reservoirs for the residents of Penadaran Village. The implementation methods used are: (1) Conducting Tuntang River Water Quality Test, (2) Designing a scheme for clean water filters and reservoirs, (3) Making clean water filters and reservoirs. The location is in Kedungkakap Hamlet, Penadaran Village. The implementation time is August - October 2021. The results of the implementation of community service, obtained the results of the Tuntang River Water Quality Test, namely, Iron: $0.496 \mathrm{mg} / \mathrm{L}$, COD: $301 \mathrm{mg} / \mathrm{L}$, Chloride: $7.30 \mathrm{mg} / \mathrm{L}$, manganese: $0.502 \mathrm{mg} / \mathrm{L}$, the river water filter scheme uses a system with 3 settling tanks and 2 mixed bed tubes. The shelter uses a $3300 \mathrm{ml}$ Toren with a tower as high as $3 \mathrm{~m}$ from the ground. There are 17 families who have received clean water supply from the new source.
\end{abstract}

Keywords: Water reservoir, River water filter, Penadaran

\begin{abstract}
Abstrak
Desa Penadaran adalah sebuah desa di Kecamatan Gubug, Kabupaten Grobogan, Provinsi Jawa Tengah. Musim kemarau membuat penduduk di Desa Penadaran mengalami masalah sumber air bersih. Tujuan Pengabdian masyarakat untuk membuat filter dan menyediakan penampungan air bersih bagi warga Desa Penadaran. Metode pelaksanaan yang digunakan adalah: (1) Melakukan Uji Kualitas Air Sungai Tuntang, (2) Merancang skema filter dan penampungan air bersih, (3) Pembuatan filter dan penampungan air bersih. Lokasi di Dusun Kedungkakap Desa Penadaran. Waktu pelaksanaan bulan Agustus - Oktober 2021. Hasil pelaksanaan pengabdian masyarakat, didapatkan hasil Uji Kualitas Air Sungai Tuntang yaitu, COD: 301 mg/L, Besi: 0,496 mg/L , mangan: 0,502 mg/L, Klorida: 7,30 mg/L, skema filter air sungai menggunakan system dengan 3 bak pengendapan dan 2 Tabung mixed bed. Penampungan menggunakan Toren ukuran $3300 \mathrm{ml}$ dengan tower setinggi $3 \mathrm{~m}$ dari permukaan tanah. Terdapat $17 \mathrm{KK}$ yang sudah mendapatkan pasokan air bersih dari sumber baru tersebut.
\end{abstract}

Kata kunci: Penampungan air, Filter air sungai, Penadaran

\section{PENDAHULUAN}

Desa Penadaran adalah sebuah desa di Kecamatan Gubug, Kabupaten Grobogan, Provinsi Jawa Tengah, Indonesia. Kecamatan ini berjarak $30 \mathrm{Km}$ dari Kota Purwodadi, ibu kota Kabupaten Grobogan, ke arah barat. Pusat pemerintahannya berada di Desa Gubug. Kecamatan Gubug adalah kecamatan terbesar serta jumlah penduduk terpadat kedua di Kabupaten Grobogan. Mata pencaharian penduduk mayoritas adalah sebagai petani padi dengan musim tanam maksimal 2 kali setahun. Sistem pengairan sawah, $45 \%$ adalah sistem tadah hujan, pengairan diperoleh dari sungai Tuntang yang bermata air di Ambarawa. Secara kuantitatif kebutuhan air bersih Desa Penadaran belum tercukupi, lebih-lebih saat 
pergantian musim dari musim penghujan ke musim kemarau membuat penduduk di Desa Penadaran mengalami masalah keterbatasan sumber air bersih karena tanah di daerah ini cenderung kering.

Masyarakat masih kesulitan dalam memenuhi kebutuhan air bersih untuk kebutuhan sehari-hari. Berbagai upaya telah dilakukan untuk mendapatkan sumber air bersih dengan melakukan pengeboran di berbagai titik lokasi di desa untuk mencari sumber air bersih yang akan digunakan untuk memenuhi kebutuhan warga. Upaya tersebut tidak berbuah baik, pada beberapa lokasi, pengeboran dilakukan hingga mencapai kedalaman 50m tetapi tidak ada sumber air bersih yang didapatkan. Tidak tentunya keberadaan sumber air bersih menyebabkan tidak meratanya pendistribusian air di Desa Penadaran. Beberapa penduduk hanya mengandalkan air dari sumur galian, sehingga sewaktu-waktu bisa kering. Oleh sebab itu, banyak warga yang memilih melakukan aktivitas di sungai Tuntang seperti mandi dan mencuci baju. Berbanding terbalik dengan kondisi tersebut, pada saat musim penghujan, sumur-sumur akan terisi penuh, bahkan genangan akan memenuhi jalan-jalan baik jalan protokol maupun jalan lingkungan.

Desa Penadaran dilewati oleh sungai tuntang dengan debit yang stabil setiap tahunnya. Aliran Kali Tuntang bersumber dari danau alam Rawa Pening di Ambarawa dan mengalir ke arah Timur melewati Grobogan lalu berbelok di Saban (40 km dari Semarang) menuju Demak, sebelum akhirnya bermuara di Laut Jawa. Daerah tangkapan Kali Tuntang dibatasi oleh Gunung Merbabu, Telomoyo, dan Ungaran. Luas DAS Kali Tuntang sebesar $\pm 796 \mathrm{~km} 2$ dengan panjang sungai dari Rawapening sampai dengan Bendung Glapan $\pm 75 \mathrm{~km}$ dengan kemiringan cukup curam lebih dari 0.025. Sedangkan kemiringan sungai dari Bendung Glapan sampai muara Laut Jawa cukup datar yaitu kurang dari 0.001 dengan Panjang sungai $\pm 49 \mathrm{~km}$. Kali Tuntang merupakan salah satu sungai yang memiliki potensi pemanfaatan air yang tinggi. Maka dari itu, sungai tuntang menjadi satu-satunya harapan bagi warga desa penadaran untuk menjadi sumber air bersih yang tidak akan pernah kering meskipun pada musim kemarau.

Sebelum mencapai Desa Penadaran, sungai tuntang sudah banyak dimanfaatkan untuk berbagai aktivitas diantaranya, PLTA, PDAM, dan jalur kereta api. Melihat aktivitas tersebut, sudah bisa dipastikan akan terjadi penurunan kualitas air karena adanya residu buangan sebagai dampak aktivitas industri. Penggunaan air sungai yang tercemar untuk aktifitas sehari-hari memiliki efek kesehatan yang cukup berbahaya, diantaranya penyakit kulit dan gangguan pencernaan. Berdasarkan latar belakang diatas, maka perlu dilakukan pembuatan dan pemasangan filter air sungai dan penampungan air bersih untuk memenuhi kebutuhan air bersih bagi warga desa penadaran.

\section{METODE}

1. Analisis Uji Kualitas Air Sungai Tuntang

Sungai Tuntang memiliki debit 722,4 m3/ detik, uji kualitas Air Sungai Tuntang berdasarkan Parameter Fisika dan Parameter Kimia. Pengambilan sampel air sungai dilakukan pada satu titik lokasi pukul 08.00 WIB, pengambilan dilakukan oleh warga sekitar menggunakan jerigen air sebanyak 5 liter dengan kedalaman pengambilan yaitu $30 \mathrm{~cm}$ dibawah permukaan air. Selanjutnya sampel diserahkan ke Laboratorium Balai Kesehatan Lingkungan di jalan Arteri Soekarno Hatta Semarang pada pukul 10.00 WIB. Pengangkutan sampel ditempatkan pada jerigen dengan dibungkus plastik hitam kemudian ditutup lagi dengan tas. Baku mutu yang digunakan adalah PP RI Np0. 82 Tahun 2001 tentang Pengelolaan Kualitas Air dan Pengendalian Pencemaran Air dengan jenis sampel: Air Badan Kelas 1.

2. Perancangan skema filter air sungai dan penampungan air bersih

Perancangan skema akan dirancang berdasarkan hasil uji analisis kualitas air sungai, untuk mendapatkan rancangan yang tepat dan sesuai dengan kondisi air dan peruntukannya. Skema penampungan air sungai dirancangan dengan mempertimbangkan kondisi tanah di Desa Penadaran yang memiliki jenis tanah alluvial, yaitu tanah ini sangat cocok untuk pertanian baik pertanian padi maupun palawija seperti jagung, tembakau dan jenis tanaman lainnya karena teksturnya yang 
lembut dan mudah digarap sehingga tidak perlu membutuhkan kerja yang keras untuk mencangkulnya. Tanah ini cenderung mudah longsor. Skema sederhana akan digambar menggunakan Microsoft Word.

3. Pembuatan dan Pemasangan Filter Air Sungai dan Penampungan Air Bersih

Setelah didapatkan skema perancangan filter air sungai dan penampungan air bersih, maka dilakukan pembuatan dan pemasangan filter air sungai dan penampungan air bersih dengan bantuan dari warga desa penadaran.

\section{HASIL DAN PEMBAHASAN}

1. Analisis Uji Kualitas Air Sungai Tuntang

Berdasarkan hasil uji analisis kualitas air, yaitu Parameter Fisik dan Parameter Kimia, dibandingkan dengan Baku mutu yang digunakan adalah PP RI Np 0. 82 Tahun 2001 tentang Pengelolaan Kualitas Air dan Pengendalian Pencemaran Air dengan jenis sampel: Air Badan Kelas 1. Didapatkan hasil bahwa pada air sungai tuntang terdapat kandungan logam berat yang cukup tinggi yaitu, Besi: 0,496 mg/L, COD: $301 \mathrm{mg} / \mathrm{L}$, pH: 7,88, mangan: 0,502 mg/L. Beberapa parameter lain yang melebihi baku mutu diantaranya, suhu yaitu 23,29' C, BOD $107 \mathrm{mg} / \mathrm{L}$, sulfida: $0,014 \mathrm{mg} / \mathrm{L}$. Total pengujian parameter ada 27 parameter, terdapat 7 parameter yang melebihi baku mutu, dan 20 lainnya normal.

Tingginya kandungan logam berat yaitu besi dan mangan dapat berdampak buruk bagi Kesehatan, yaitu alergi, gangguan kulit, dan keluhan subjektif yang lain. Kemudian dampak buruk dari tingginya kandungan COD dan BOD pada air yaitu Akibat dari konsentrasi COD yang tinggi dalam badan air menunjukkan bahwa adanya bahan pencemar organik dalam jumlah tinggi jumlah mikroorganisme baik secara patogen dan tidak patogen yang dapat menimbulkan berbagai macam penyakit untuk manusia. 


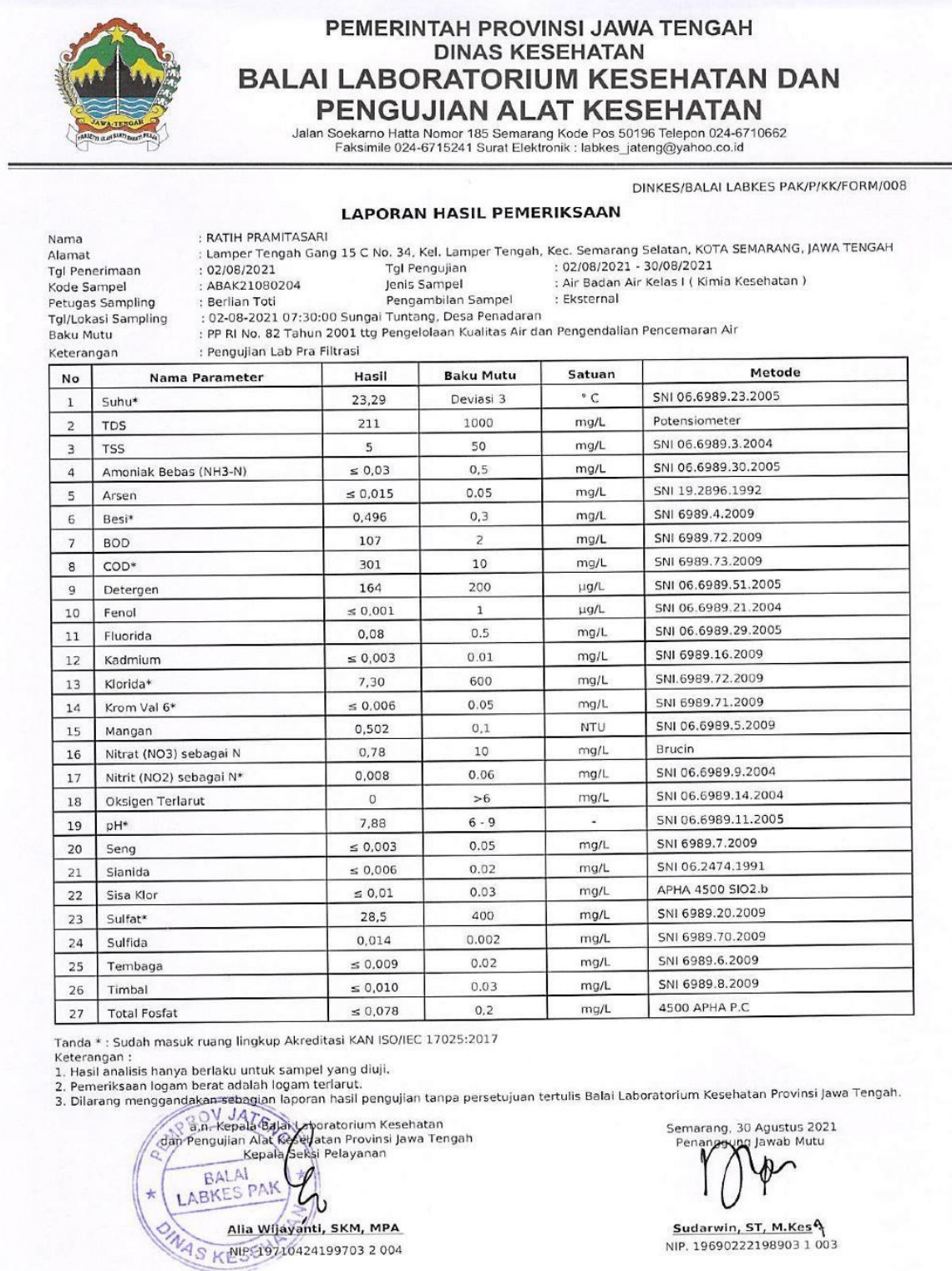

\section{Gambar 1. Hasil Uji Kualitas Air Sungai Tuntang}

2. Perancangan skema filter air sungai dan penampungan air bersih

Berdasarkan hasil yang telah didapat maka dibuatlah suatu rancangan untuk mereduksi kandungan kimia dan logam berat yang terdapat di sungai Tuntang.

1. Alur pertama yaitu air dari sungai dipompa dialirkan melalui inlet dan ditampung pada 3 gorong pengendapan.

2. Setiap gorong pengendapan terdapat serabut kelapa yang berfungsi menyaring partikel-partikel besar seperti lumpur yang terbawa oleh air sungai.

3. Air hasil penyaringan di ketiga bak pengendapan selanjutnya dipompa menuju filter air.

4. Dengan dua filter air masing-masing berisi media filtrasi yang berbeda. Filter pertama berisi 
media filter busa, gravel, karbon aktif, batu zeolit. Filter kedua berisi media busa filter, gravel, pasir manganese.

5. Hasil penyaringan oleh filter air kemudian masuk ke dalam toren penampungan air bersih.

6. Air bersih hasil proses filtrasi siap untuk didistribusikan ke rumah-rumah warga.

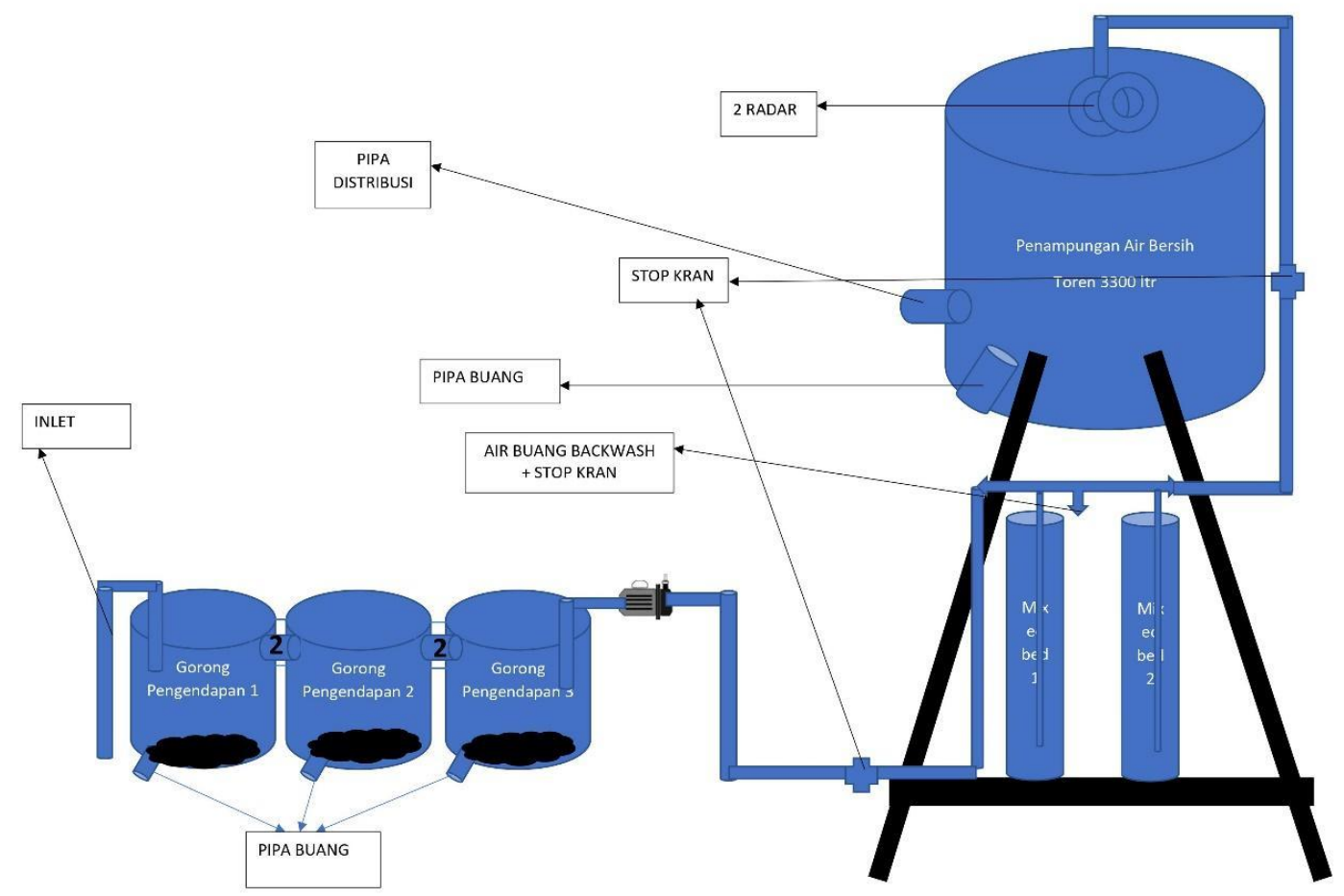

Gambar 2. Skema Filter Air Sungai dan Penampungan Air Bersih di Desa Penadaran

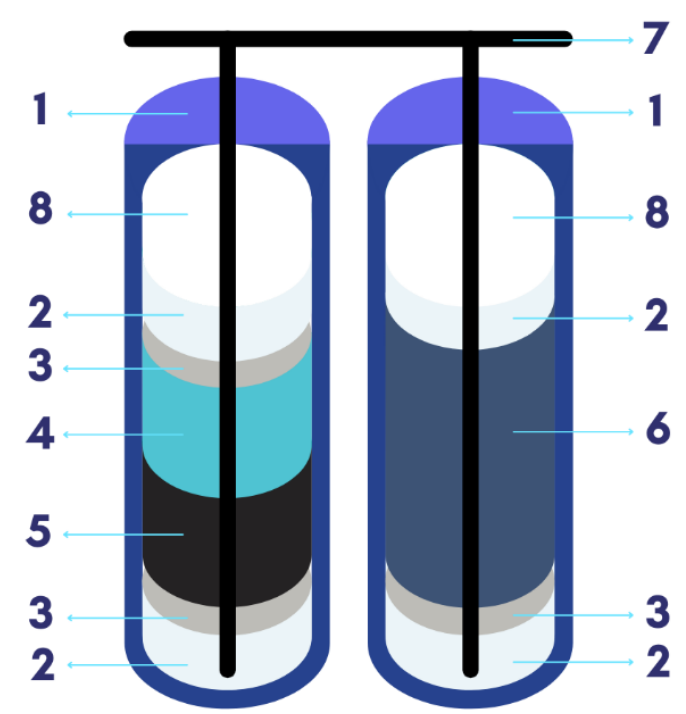

Gambar 3. Susunan Media Filter Air Sungai 
Keterangan gambar :

1 : Media Tabung Sebagai sarana tempat untuk menampung bahan - bahan filter. Yang akan diolah menjadi air bersih

2 : Busa Filter Berfungsi untuk menyerap endapan-endapan / kotoran air yang membuat air menjadi keruh.

3 : Gravel adalah menurunkan kekeruhan influen dan suspended solid sehingga memadai untuk input bagi sistem filtrasi.

4 : Batu Zeolit merupakan batu alam yang di olah sedemikian rupa sehingga memiliki kandungan hydrated silicates calcium, alumunium, sodium dan potassium. Dalam proses filter air ini zeolit berfungsi membunuh bakteri dan mengikat kandungan logam yang terkandung dalam air.

5 : Karbon aktif Karbon aktif terbuat dari batok atau tempurung kelapa yang dibakar sampai menjadi karbon. Karbon aktif berfungsi penyerap bau, menghilangkan warna kuning dan unsur yang merugikan di dalam kandungan air.

6 : Pasir Manganese Pasir manganese adalah media filter yang digunakan dalam sistem filtrasi untuk mengoksidasi, menghilangkan besi, manganese dan hidrogen sulfida

7 : Pipa Sebagai media penyalur air

8 : Ruang hampa Ruang kosong berfungsi membantu proses filtrasi pada air

3. Pembuatan dan Pemasangan Filter Air Sungai dan Penampungan Air Bersih

Berdasarkan hasil yang didapat dalam rancangan untuk dilakukannya filter air sungai. Maka langkah selanjutnya dilakukan pembuatan dan pemasangan filter air sungai serta tempat penampungan air sungai. Pada tahap ini dibuat terlebih dahulu penampungan air bersih yaitu pemasangan tower dan Toren. Pada pemasangan tower dan toren ini dilakukan oleh karang karuna dan warga Desa Penadaran yang dimana pada tinggi tower setinggi 3 meter dengan daya tampung air sebesar 3300 Liter.

Pada tahap pembuatan dan pemasangan filter air sungai yaitu dilakukan dengan menggunakan dengan bahan tabung, busa filter, gravel, batu zeolit, karbon aktif, pasir manganese, pipa dan ruang hampa yang sudah dijelaskan pada rancangan sebelumnya. Pada pembuatan filter sendiri sungai dipompa kemudian masuk ke dalam 3 gorong-gorong yang pada setiap gorong-gorong berisi serabut kelapa untuk penyaringan dan pengendapan pada air sungai yang diakibatkan oleh lumpur maupun batu-batu kecil. Kemudian setelah masuk ke gorong-gorong tersebut pada gorong-gorong ke 3 air akan dipompa kembali ke filter, kemudian air bersih yang dihasilkan oleh filter tersebut air akan naik ke dalam toren selanjutkan air tersebut dapat didistribusikan untuk warga. Adapun tahapan untuk pembuangan kotoran yang dihasilkan oleh filter tersebut menggunakan sistem Backwash. Backwash merupakan sebuah sistem pembersihan filter untuk membersihkan kandungan kotoran yang dihasilkan dalam proses filter yang terdapat pada media atau tabung filter. 

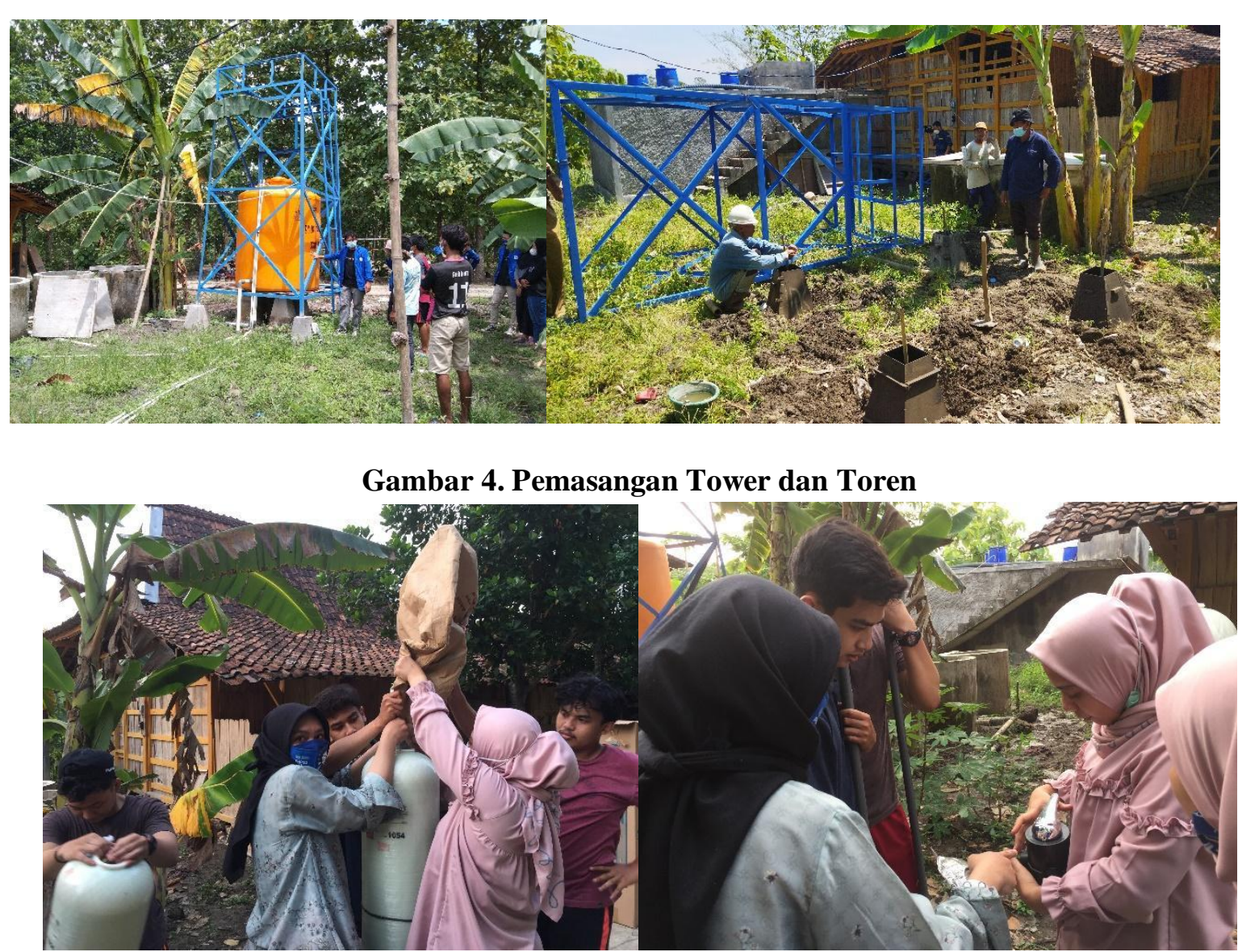

Gambar 5. Pemasangan Filter Air Sungai

\section{KESIMPULAN}

Kegiatan pengabdian kepada masyarakat berjalan dengan lancar dalam 3 kegiatan yang berlangsung yaitu Analisis Uji Kualitas Air Sungai Tuntang, Perancangan skema filter air sungai dan penampungan air bersih, Pembuatan dan Pemasangan Filter Air Sungai dan Penampungan Air Bersih. Setelah melakukan pengujian air total pengujian parameter ada sebanyak 27 parameter, ada 7 parameter yang melebihi standar baku mutu air dan 20 parameter lainnya normal. kegiatan kedua yaitu Perancangan skema filter dimulai dari dari air sungai di pompa (Inlet) masuk ke dalam 3 bak penampungan, kemudian setelah melalui ketiga bak penampung tersebut, air hasil penyaringan di bak penampungan 3 aja di pompa lagi menuju filter air, di dalam filter air tersebut terdapat media2 filtrasi. hasil dari penyaringan filter masuk ke dalam penampungan air atas, setelah itu air tersebut didistribusikan ke rumah warga. Kegiatan ketiga pembuatan dan pemasangan filter dan penampungan air untuk realisasi kegiatan ini untuk tempat penampungan air dibuat sebuah tower setinggi 3 meter dengan daya tampung air sebesar 3300 Liter, Pada tahap pembuatan dan pemasangan filter air sungai yaitu dilakukan dengan melakukan pengendapan di 3 bak untuk menyaring kotoran besar pada air sungai kemudian dilanjutkan menggunakan dengan filtrasi filter dengan sistem backwash. kemudian air dinaikan ke toren penampungan untuk didistribusikan ke warga Penadaran.

Saran dalam pelatihan ini adalah diharapkan kegiatan serupa dapat diadakan tidak hanya di lingkungan Desa Penadaran saja, mengingat bahwa pengetahuan terkait penjernihan air merupakan upaya dalam pemenuhan kebutuhan air bersih. 


\section{DAFTAR PUSTAKA}

Wicaksono B, Mayasari D, P PS, Iduwin T, Yuhanah T. Edukasi Alat Penjernih Air Sederhana Sebagai Upaya Pemenuhan Kebutuhan Air Bersih. 2019;2(1):43-52.

Arisanti D, Basarang M. Penyuluhan Kesehatan Perilaku Hidup Bersih Dan Sehat (Phbs) Tatanan Rumah Tangga Desa Bajiminasa Kec. Gantarangkeke Kabupaten Bantaeng Dewi. 2020;1(1):3842.

Udayana U. Perencanaan Penyaring Air Sederhana. 2010;1-14.

Anita, Risnawaty Alyah BA. Edukasi Perilaku Hidup Bersih Dan Sehat (Phbs) Dalam Pencegahan Covid-19 Kepada Kader Posyandu Mawar Desa Palioi Kecamatan Kindang Kabupaten Bulukumba. 2020;1(2):30-4.

Tanah D, Dan L, Padi S, Pengusul TIM. Pembuatan Filter Keramik Untuk Produksi Air Bersih. 2016;

Sunarsih E, Faisya AF, Windusari Y, Trisnaini I, Arista D, Septiawati D, et al. Analisis Paparan Kadmium , Besi , Dan Mangan Pada Air Terhadap Gangguan Kulit Pada Masyarakat Desa Ibul Besar Kecamatan Indralaya Selatan Kabupaten Ogan Ilir. 2018;17(32):68-73.

Muawanah, Darmawaty Rauf S, Program. Penyuluhan Pentingnya Penerapan Pola Hidup Bersih Dan Sehat (PHBS) Di Lingkungan Dusun Baturappe Kecamatan Biringbulu Kabupaten Gowa Muawanah*,. 2020;1(2):15-21.

Tepat P, Kesehatan G, Inti M. Penyaringan (filtrasi) air dengan metode saringan pasir cepat. :1-16.

Tepat P, Kesehatan G, Inti M. Penjernihan air dengan metode aerasi \& filtrasi. :1-19.

Jefri M. Penyaringan Air Sederhana. 2016;1-16. 